\title{
The hemostatic activity of Manilkara zapota (L.) P. Royen latex associ- ated with fibrinogenolytic activity
}

\author{
C.G. Kusuma ${ }^{1}$, Vinod Gubbiveeranna ${ }^{1}$, C.K. Sumachirayu ${ }^{1}$, S. Bhavana ${ }^{1}$, H. Ravikumar ${ }^{2} \&$ S. Nagaraju ${ }^{1 *}$ \\ ${ }^{1}$ Department of Studies and Research in Biochemistry, Tumkur University, Tumkur, 572 103, Karnataka, India \\ ${ }^{2}$ Department of Biological Sciences, Jnana Bharathi Campus, Bangalore University, Bangalore, 560 056, Karnataka, India \\ *Email: nagarajubiochem@gmail.com
}

\section{ARTICLE HISTORY}

Received: 11 March 2020

Accepted: 14 July 2020

Published: 04 August 2020

KEYWORDS

Proteolytic

Procoagulant

Serine protease

Collagenolytic

\section{ABSTRACT}

Manilkara zapota (L.) P. Royen (Sapotaceae), is widely used in traditional medicine for various ailments like, diarrhea, pulmonary diseases, piles, ulcers and to treat wounds. The present study evaluates the role of M. zapota latex in hemostasis. The processed latex named as M. zapota natant latex (MzNL), has proteins at the concentration of $8 \mathrm{mg} / \mathrm{ml}$ and showed protein bands in Sodium dodecyl sulfatepolyacrylamide gel electrophoresis (SDS-PAGE). The proteolytic activity of MzNL was evaluated using casein in comparison with trypsin. The phenylmethylsulfonyl fluoride (PMSF) inhibited the protease activity indicating the possible presence of serine protease. The effect of temperature, $\mathrm{pH}$ and metal ions on proteolytic activity was evaluated. MzNL exhibited fibrinogenolytic activity by hydrolysing $\mathrm{Aa}$ and $B \beta$ subunits of fibrinogen. However, $\gamma$ subunit remained resistant for hydrolysis. MzNL hydrolyzed all the subunits of collagen type I and IV at the concentration of $8 \mu \mathrm{g}$ and $25 \mu \mathrm{g}$ in $20 \mu \mathrm{l}$ each respectively. MzNL showed procoagulant activity and is devoid of hemolytic activity. Fibrinogenolytic activity and procoagulant nature of MzNL suggests its possible role in blood coagulation that in turn restores hemostasis.

\section{Introduction}

Hemostasis is a complex process to avoid loss of blood during injury. It is regulated by interactions of blood vasculatures, platelets, cytokine mediators, coagulation factors and fibrinolytic proteins. During injury to the blood vessel, platelets and immune cells enters injured site to initiate blood coagulation and wound healing. Simultaneously the exposed sub-endothelial collagen triggers the activation of intrinsic pathway and tissue factor initiates extrinsic pathway of blood coagulation cascade. Both the pathways activate coagulation proteins in cascade manner and enters common pathway by activating Factor X. This in turn activates thrombin which forms fibrin mesh from the fibrinogen, avoiding blood loss (1). The cascade of activation of coagulation factors is represented in Fig. 1.

Several hemostatic components have been reported from different sources such as venoms, microbes and plants latex (2-4). Plant latex has been extensively used to stop bleeding from fresh cuts and to

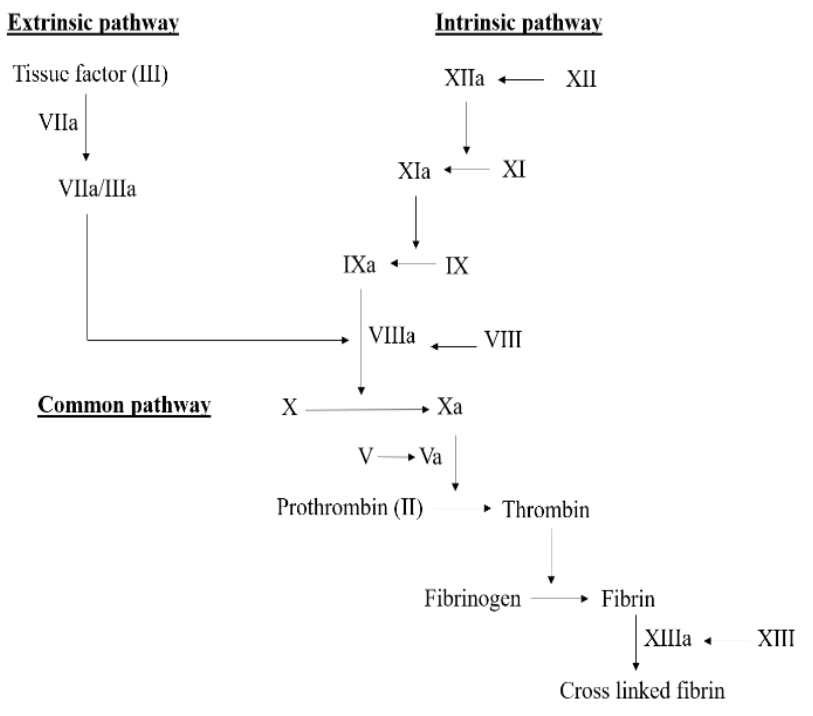

Fig. 1. Schematic representation of blood coagulation cascade

(c) Kusuma et al (2020). This is an open-access article distributed under the terms of the Creative Commons Attribution License, which permits unrestricted use, distribution and reproduction in any medium, provided the original author and source are credited (https://creativecommons.org/licenses/by/4.0/).

To cite this article: Kusuma C G, Gubbiveeranna V, Sumachirayu C K, Bhavana S, Ravikumar H, Nagaraju S. The hemostatic activity of Manilkara zapota (L.) P. Royen latex associated with fibrinogenolytic activity. Plant Science Today. 2020;7(3):469-475. https://doi.org/10.14719/pst.2020.7.3.775 
enhance the wound healing process in folklore medication (5). Proteases in plant latex are reported to be the causative agent for hemostatic effect. Latex proteases interfere in coagulation pathway majorly at the common pathway $(5,6)$. Some latex proteases mimic the activity of thrombin, these thrombin-like enzymes convert fibrinogen to fibrin (7).

The $M$. zapota is one such latex producing evergreen tree belonging to the family Sapotaceae. The plant is native to Southern Mexico, north-eastern Guatemala and Northern Bleize. The plant has been cultivated abundantly in Central America, Caribbean islands and also in Asian countries like Malaysia, Bangladesh, India, Pakistan, Thailand, Cambodia and Indonesia (8). The plant has named differently in different countries; Chickoosapote, Chickoozapote (Mexico, Hawai, California, southern Florida), Cheeku (Urdu). Chickoo, Sapota (Hindi), Sopeta, Sofeda (Bengali), Lamut farang (Thai), Sapoti (Brazil, Haiti), Ciku, Sawo manila (Malay), Nispero (Colombia, Venezuela) $(9,10)$. The image of plant and its fertile parts are represented in Fig. 2, (11).

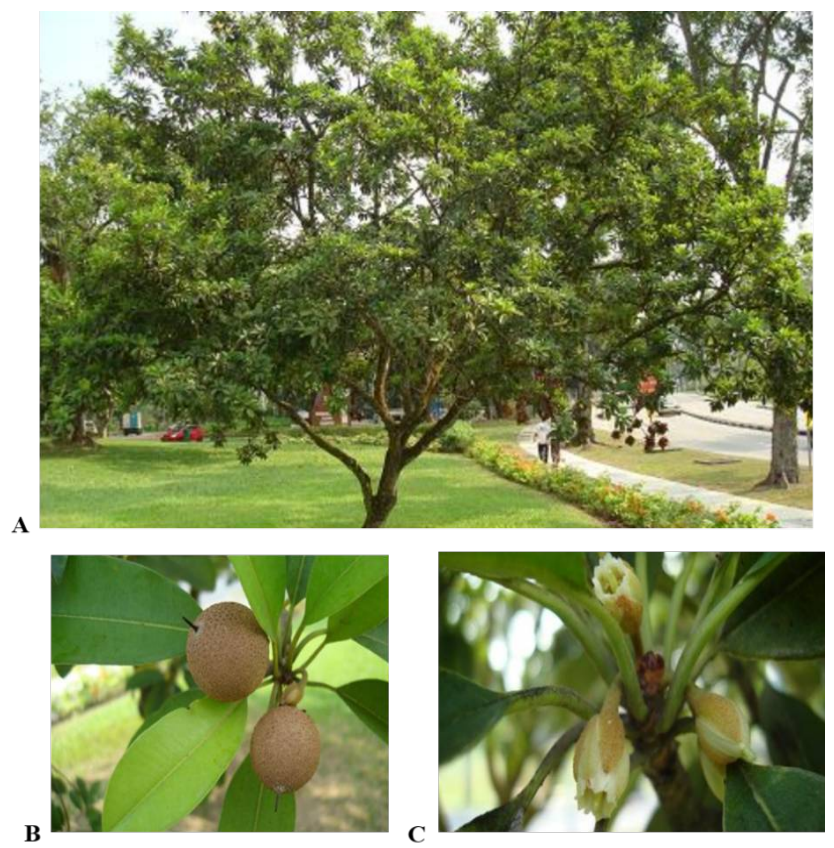

Fig. 2. A. Habit of M. zapota, B. Fruit, C. Flower.

Traditionally most parts of $M$. zapota plant have been used for medicinal purposes; latex from $M$. $z a-$ pota is coagulated to form chickle, used to prepare chewing gums (12). The fruits, leaves and bark are used to treat diarrhea and pulmonary diseases. Fruits have reported reducing inflammation and pain in gastritis (13). The paste prepared from seed used to reduce pain and inflammation caused by bites and stings (14). In folk medicine the juice prepared from the leaf of $M$. zapota is used to treat wounds and ulcers. There are reports on the significance of leaves extracts from $M$. zapota on corneal wound healing activity (15).

Based on the pharmacological properties and the traditional usage, an attempt has been made to evaluate the hemostatic property of $M$. zapota latex.

\section{Materials and Methods}

\section{Chemicals}

Casein, gelatin (from porcine skin), fibrinogen (from human plasma), collagen type I (from rat tail), collagen type IV (from the human placenta), E-64, PMSF, ethylenediaminetetraacetic acid (EDTA) and pepstatin A from Sigma Aldrich (St. Louis, MO, USA). Trypsin from HiMedia (Mumbai, Maharashtra, India), and all other reagents used were of analytical grade.

\section{Latex collection and processing}

The M. zapota latex was collected near Tumkur, Karnataka, India, in the month of March. The plant was identified by Dr. P. Sharanappa, Professor, Department of Studies and Research in Bioscience, Hemagangotri, University of Mysore, Hassan, Karnataka, India. The voucher specimen (TU16DOSRBC004) for M. zapota plant is deposited in the herbarium of the Department of Studies and Research in Botany, Tumkur University, Tumkur, Karnataka, India.

Latex of M. zapota was collected in a clean container from freshly plucked half ripened fruit and freeze overnight at $-20{ }^{\circ} \mathrm{C}$. The latex thawed and processed in centrifuge (RemiC-24BL, Maharashtra, India) with speed $10000 \mathrm{rpm}$ for $20 \mathrm{~min}$; the supernatant was subjected to dialysis using cellulose membrane having molecular cut off of $12 \mathrm{kDa}$ against distilled water for $24 \mathrm{hr}$. The obtained clear protein-rich latex was named as MzNL.

\section{Protease activity}

Protease activity was analysed as explained as per the procedure mentioned (16). The casein (2\%) dissolved in $200 \mathrm{mM}$ Tris-HCl buffer ( $\mathrm{pH} 7.0)$ was used as substrate. Various concentrations of MzNL (0-200 $\mu \mathrm{g} / 20 \mu \mathrm{l})$ along with standard trypsin were incubated with $0.4 \mathrm{ml}$ of casein separately at temperature $37{ }^{\circ} \mathrm{C}$ for $2 \mathrm{hrs} 30 \mathrm{~min}$. This reaction was terminated using $1.5 \mathrm{ml}$ of trichloroacetic acid $(0.44 \mathrm{M})$; After $30 \mathrm{~min}$, centrifugation was done with the speed $3000 \mathrm{rpm}$ for $5 \mathrm{~min}$. To the $1 \mathrm{ml}$ of supernatant $0.4 \mathrm{M}$ sodium carbonate $(2.5 \mathrm{ml})$ and 1:2 diluted Folin-Ciocalteu (FC) $(0.5 \mathrm{ml})$ reagents were added and incubated at $37^{\circ} \mathrm{C}$ for $20 \mathrm{~min}$. The developed colour was analysed at 660 nm (BioSpectrometer Kinetic, Eppendorf, CA, USA). One unit of enzyme activity is stated as the amount of enzyme required to increase the absorbance by 0.01 at $660 \mathrm{~nm}$ in $1 \mathrm{hr}$.

\section{Effect of temperature, $p H$, inhibitors and metal ions on protease activity}

Effect of temperature and $\mathrm{pH}$ on protease activity was tested by incubating $80 \mu \mathrm{g}$ of MzNL at different temperatures $\left(0{ }^{\circ} \mathrm{C}-80{ }^{\circ} \mathrm{C}\right)$ and $\mathrm{pH}(3-12)$ for $30 \mathrm{~min}$. Later, the proteolytic activity was measured (16). For inhibition studies, the experiment was repeated with $30 \mathrm{~min}$ prior incubation of MzNL $(80 \mu \mathrm{g})$ with $5 \mathrm{mM}$ concentrations of standard protease inhibitors (E-64, EDTA, PMSF, pepstatin A). Effect of metal ions was evaluated by incubating $10 \mathrm{mM}$ concentrations of different metal ions such as $\mathrm{Ba}^{2+}, \mathrm{K}^{+}, \mathrm{Na}^{+}, \mathrm{Ca}^{2+}, \mathrm{Mg}^{2+}, \mathrm{Zn}^{2+}$, $\mathrm{Mn}^{2+}$ and $\mathrm{Cu}^{2+}$ with $80 \mu \mathrm{g}$ of MzNL separately for 30 min. Further, proteolytic activity was evaluated as per procedure (16). 


\section{Electrophoresis and zymography}

SDS-PAGE was performed as explained in Laemmli (17). MzNL $(80 \mu \mathrm{g})$ was treated with a non-reducing sample buffer and boiled for $3 \mathrm{~min}$. SDS-PAGE (10\%) was performed for MzNL and molecular weight standards ranging between $14.2-97.0 \mathrm{kDa}$. The protein bands obtained were detected using $0.25 \%$ Coomassie brilliant blue R-250 (CBBR-250).

Periodic acid-Schiff base (PAS) staining was performed (18). SDS-PAGE was performed for $80 \mu \mathrm{g}$ of MzNL and $50 \mu \mathrm{g}$ of fibrinogen. The gel was fixed in $7.5 \%$ acetic acid at temperature $37^{\circ} \mathrm{C}$ for one $\mathrm{hr}$, and then washed with nitric acid. Further, the gel was kept at $4{ }^{\circ} \mathrm{C}$ in aqueous periodic acid $(0.2 \%)$ for 45 min. This gel was stored overnight at $4{ }^{\circ} \mathrm{C}$ in the Schiff reagent. To visualize the reddish-pink bands the gel was de-stained with $10 \%$ acetic acid.

Zymography was performed (17). The $10 \%$ SDSPAGE was performed for $80 \mu \mathrm{g}$ of MzNL, where the resolving gel was incorporated with $0.2 \%$ casein/ gelatin separately. After electrophoresis, the SDS was removed by washing the gel using Triton X-100 (2.5\%). Further, the gel was incubated in Tris- $\mathrm{HCl}$ (50 $\mathrm{mM}$; pH 7.0) buffer containing $\mathrm{CaCl}_{2}(10 \mathrm{mM})$ and $\mathrm{NaCl}(150 \mathrm{mM})$. The gel was stained using CBBR-250 $(0.25 \%)$ to observe activity bands.

\section{Fibrinogenolytic activity}

The fibrinogenolytic activity was evaluated (3). $50 \mu \mathrm{g}$ of human fibrinogen was treated with various concentrations $(0-15 \mu \mathrm{g} / 20 \mu \mathrm{l})$ of $\mathrm{MzNL}$ at $37^{\circ} \mathrm{C}$ for $2 \mathrm{hrs}$ $30 \mathrm{~min}$. Reducing sample buffer $(10 \mu \mathrm{l})$ was used to terminate the reaction. The hydrolysed products were analysed in SDS-PAGE (12\%) and stained with $0.25 \%$ of CBBR-250 to visualize bands.

\section{Recalcification time}

Recalcification time assay was carried out (19). Different concentration (50-150 $\mu \mathrm{g} / 20 \mu \mathrm{l}$ ) of MzNL was treated with $100 \mu \mathrm{l}$ of citrated plasma from goat at 37 ${ }^{\circ} \mathrm{C}$ for $5 \mathrm{~min}$. Further, $25 \mathrm{mM} \mathrm{CaCl}_{2}(100 \mu \mathrm{l})$ was added and recorded the time until the formation of a clot.

\section{Collagenolytic activity}

The collagenolytic activity was identified (20). Type I $(10 \mu \mathrm{g})$ and IV $(25 \mu \mathrm{g})$ collagens were treated with different concentrations of MzNL (2-8 $\mu \mathrm{g} / 20 \mu \mathrm{l}$ for type I and $2-25 \mu \mathrm{g} / 20 \mu \mathrm{l}$ for type IV) and incubated at $37^{\circ} \mathrm{C}$ for $2 \mathrm{hrs} 30 \mathrm{~min}$. Reducing sample buffer $(5 \mu \mathrm{l})$ was used to stop the reaction. Hydrolysed products were analysed in SDS-PAGE (7\%) and stained with $0.25 \%$ CBBR-250.

\section{Hemolytic activity}

The assay was carried out (21). Blood from a healthy goat was treated with $3.2 \%$ of trisodium citrate in the ratio 1:9 and centrifuged for $5 \mathrm{~min}$ at speed $3000 \mathrm{rpm}$ to obtain red blood cell (RBC) pellet. The pellet was washed and re-suspended in normal saline $(0.9 \%$ $\mathrm{NaCl}$ ) to obtain $2 \%$ erythrocyte suspension. The MzNL with the concentration ranging from $0-500 \mu \mathrm{g} / 50 \mu \mathrm{l}$ were treated with $0.5 \mathrm{ml}$ erythrocyte suspension in a reaction volume of $1 \mathrm{ml}$ made with saline and incu- bated at temperature $37{ }^{\circ} \mathrm{C}$ for $30 \mathrm{~min}$. Further, normal saline $(2 \mathrm{ml})$ was pipette to the mixture and this mixture was subjected to centrifugation at speed $1500 \mathrm{rpm}$ for 2-3 min. The amount of free hemoglobin was measured from $1 \mathrm{ml}$ of the supernatant at $540 \mathrm{~nm}$. The absorbance obtained while using normal saline was considered as $0 \%$ and water as $100 \%$.

\section{Protein estimation}

The protein estimation was performed (22). The protein measured with the Folin's phenol reagent, where bovine serum albumin was used as standard.

\section{Statistical analysis}

Results were represented as mean \pm standard error. One-way analysis of variance was used for statistical significance of intergroup differences and the Tukey test was used for comparison of means. The Statistical Package for Social Sciences (SPSS) version 15.0 (SPSS Inc., Chicago, IL, USA) was used to perform all analysis.

\section{Results and Discussion}

In this study, we have evaluated the MzNL for proteolytic activity and its effect on hemostasis. The MzNL has a protein concentration of $8 \mathrm{mg} / \mathrm{ml}$. Analysis of MzNL by SDS-PAGE showed protein bands distributed between 14-65 kDa (Fig. 3A). PAS staining showed the presence of glycosylated proteins among them (Fig. 3B). The plants latex is known to contain a wide range of proteases which function in its physiology and their defence mechanism (7). MzNL was evaluated for proteolytic activity in comparison with trypsin using casein as a substrate, where, MzNL showed less proteolytic activity compared to trypsin (Fig. 4). Further, MzNL in zymogram assay (using casein and gelatin as substrate) exhibited translucent activity bands, confirming the presence of protease(s) in the sample (Fig. 3C). Proteases from plant latex have broad substrate specificity. They can hydrolyse casein, gelatin and extracellular matrix $(3,23)$.

MzNL showed optimal proteolytic activity at temperature $27^{\circ} \mathrm{C}$ (Fig. 5A) and pH 7.0 (Fig. 5B). To evaluate the type of protease in MzNL sample, standard inhibitors for protease was used to estimate the proteolytic activity. PMSF maximally inhibited the proteolytic activity of MzNL, indicating the presence of the serine type of protease (Fig. 5C). The metal ions effect on the proteolytic activity of MzNL was carried out by treating $10 \mathrm{mM}$ concentration of various salts containing monovalent $\left(\mathrm{K}^{+}, \mathrm{Na}^{+}\right)$and divalent ions $\left(\mathrm{Ba}^{2+}, \mathrm{Ca}^{2+}, \mathrm{Mg}^{2+}, \mathrm{Zn}^{2+}, \mathrm{Mn}^{2+}\right.$ and $\left.\mathrm{Cu}^{2+}\right)$ with MzNL for 30 min. Among the ions, $\mathrm{Mn}^{2+}$ and $\mathrm{Cu}^{2+}$ showed an inhibitory effect of up to $47 \%$ and $25 \%$ respectively (Fig. 5D).

In mammalian blood coagulation system, direct involvement of serine proteases is observed. The extrinsic and intrinsic pathways culminate in common pathway of blood coagulation and converts fibrinogen to fibrin. Fibrinogen is hydrolysed by thrombin and polymerizes to insoluble fibrin threads. Cleaving at specific sites of fibrinogen by thrombin forms fibrinopeptides A and B $(1,24)$. Studies show that many 
plant latexes showed thrombin-like activity by hydrolyzing fibrinogen and they were pro-coagulant in nature $(5,6)$. MzNL was checked for its action on fibrinogen by incubated $50 \mu \mathrm{g}$ of pure fibrinogen with different concentration of MzNL 0-15 $\mu \mathrm{g} / 20 \mu \mathrm{l}$ for 2 hrs $30 \mathrm{~min}$ and analysed on SDS-PAGE under reduced
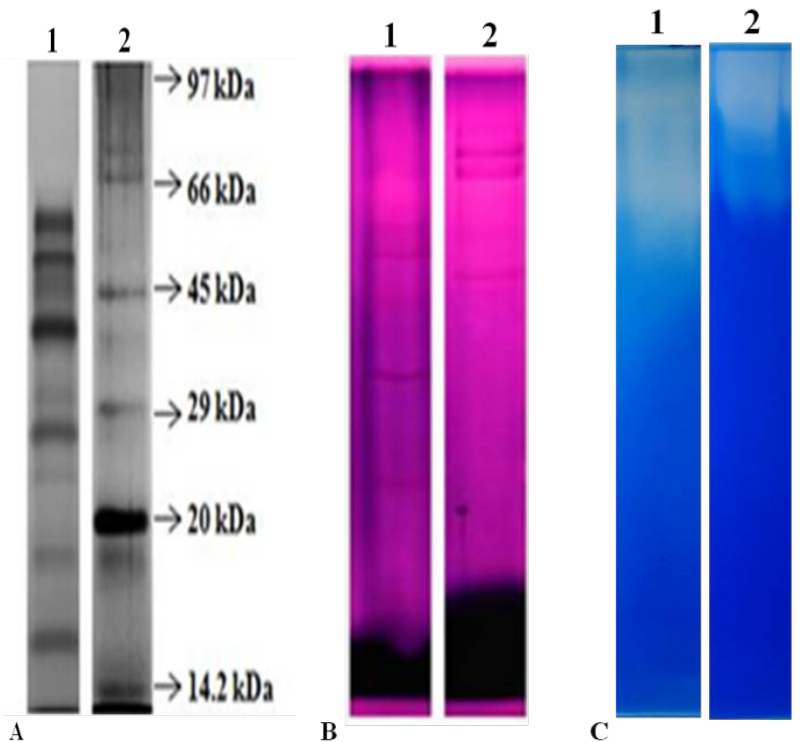

Fig. 3. Electrophoresis and zymography A. SDS-PAGE (10\%) was performed under non-reducing condition and stained with $0.25 \%$ CBBR-250. Lane 1: MzNL (80 $\mu \mathrm{g})$; lane 2: molecular-weight markers. B. The SDS-PAGE performed was subjected to PAS staining for glycoprotein observation. Lane 1: MzNL $(80 \mu \mathrm{g})$; lane 2: fibrinogen (50 $\mu \mathrm{g})$; positive control. C. Zymogram of MzNL $(80 \mu \mathrm{g})$. Lane 1: gelatinolytic zymogram; lane 2: caseinolytic zymogram. SDS-PAGE, sodium dodecyl sulfate-polyacrylamide gel electrophoresis; CBBR250, coomassie brilliant blue R-250; MzNL, M. zapota natant latex; PAS, periodic acid-Schiff base.

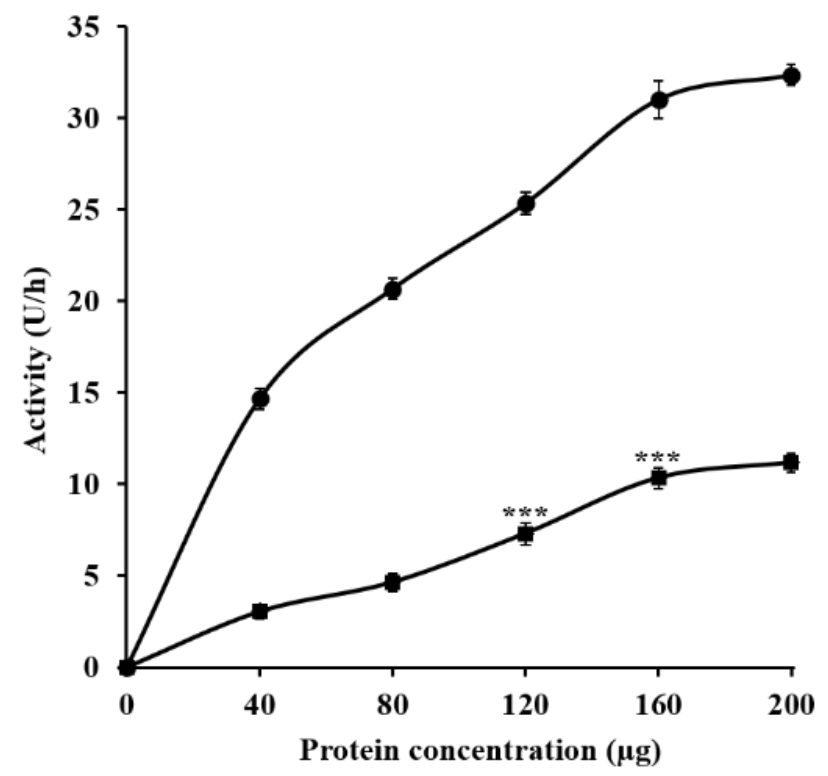

Fig. 4. Protease activity Different concentrations $(0-200 \mu \mathrm{g} / 20 \mu \mathrm{l})$ of MzNL $(\boldsymbol{\square})$ and trypsin $(\bullet)$ were treated with $2 \%$ casein for 2 hours $30 \mathrm{~min}$ at $37^{\circ} \mathrm{C}$. The proteolytic activity has expressed in $\mathrm{U} / \mathrm{h}$. Values are presented as mean \pm standard error of the mean $(n=3)$ Statistically significant results are indicated by asterisks, ${ }^{* * *}-p<$ 0.001 . MzNL, M. zapota natant latex.

condition. MzNL cleaved Aa and B $\beta$ subunits of fibrinogen completely at concentrations $0.25 \mu \mathrm{g} / 20 \mu \mathrm{l}$
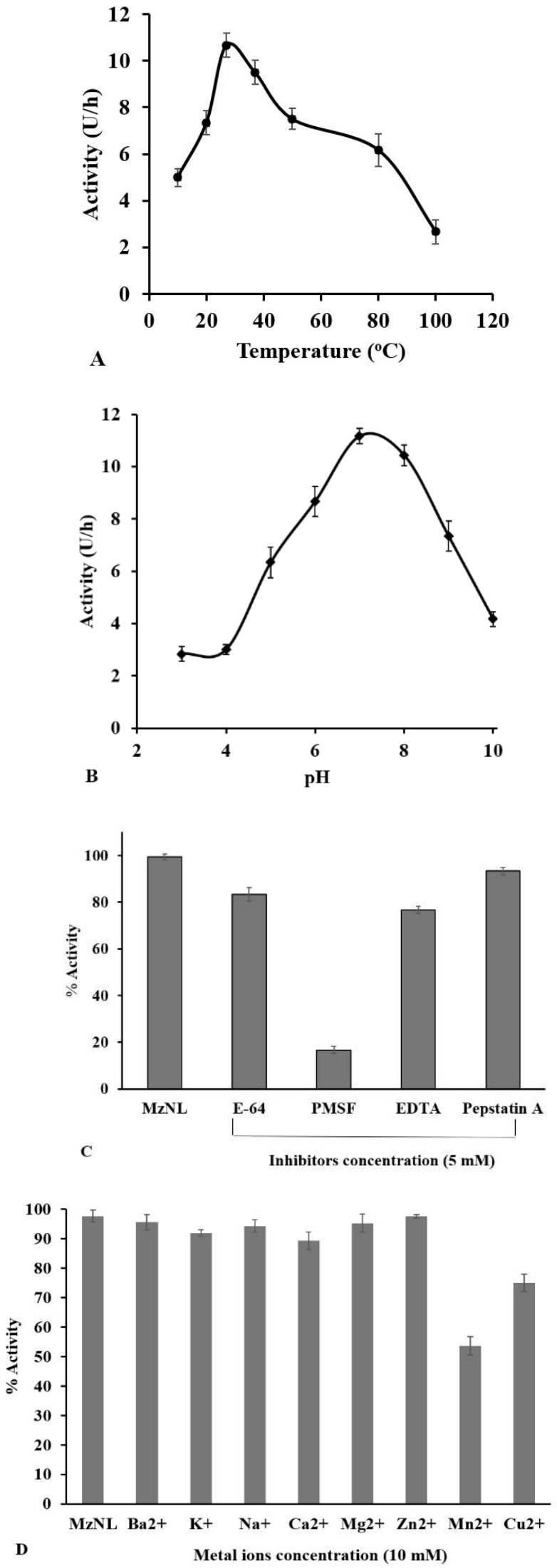

Fig. 5. Effect of temperature, $\mathbf{p H}$, inhibitors and metal ions on protease activity of MzNL $(80 \mu \mathrm{g} / 20 \mu \mathrm{l})$. A. Effect of temperature; optimum temperature found to be $27{ }^{\circ} \mathrm{C}$. B. Effect of $\mathrm{pH}$; optimum $\mathrm{pH}$ was 7.0.C. Effect of inhibitors; maximum inhibition observed with PMSF indicating the presence of serine protease. D. Effect of metal ions; $\mathrm{Mn}^{2+}$ and $\mathrm{Cu}^{2+}$ inhibited protease activity of MzNL by 47\% and 25\% respectively. MzNL, M. zapota natant latex; PMSF, phenylmethylsulfonyl fluoride. 
and $4 \mu \mathrm{g} / 20 \mu \mathrm{l}$ respectively. However, $\gamma$ subunit was not hydrolysed even at $15 \mu \mathrm{g} / 20 \mu \mathrm{l}$ of MzNL. Hydrolysis of fibrinogen by MzNL generated small molecular weight proteins and intensity of these proteins band were increased dose-dependently (Fig. 6). MzNL showed pro-coagulant effect in recalcification time. The clotting time of plasma was reduced from $143 \mathrm{~s}$ to $35 \mathrm{~s}$ with MzNL at a concentration of $150 \mu \mathrm{g} / 20 \mu \mathrm{l}$ (Fig. 7).

Latex from many plants like Calotropis gigantea, Wrightia tinctoria, Synadenium grantii, Cryptostegia grandiflora, Plumeria rubra, Pedilanthus tithymaloides and Euphorbia nivulia (24-26) have showed procoagulant property. Few of them showed proteases are responsible for observed activity. Most of the proteases belongs to cysteine and serine class of proteases. To name few proteases, Pergularain e I, Hirtin and Heynein from the plants Pergularia extensa, Euphorbia hirta and Ervatamia heyneana respectively have been identified and purified (27-29).

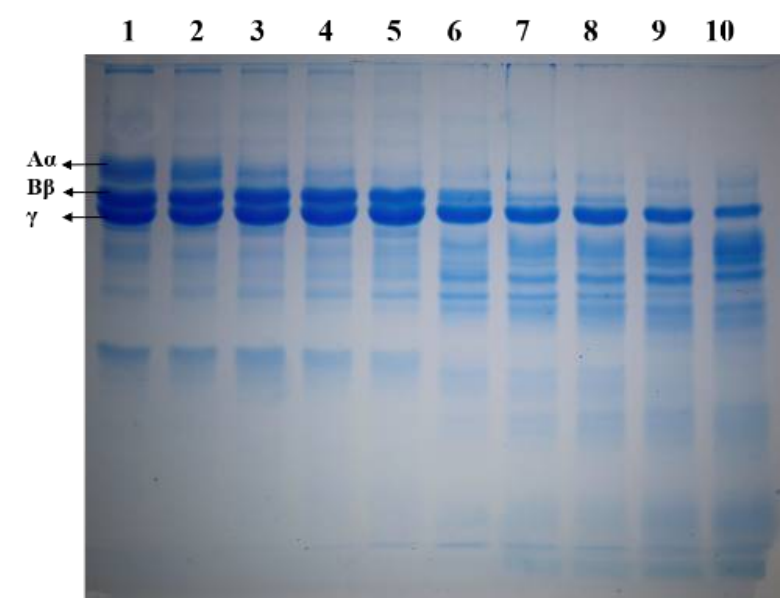

Fig. 6. Fibrinogenolytic activity. The $50 \mu \mathrm{g}$ of human fibrinogen was incubated with various concentrations of MzNL $(0-15 \mu \mathrm{g} / 20 \mu \mathrm{l})$ at $37{ }^{\circ} \mathrm{C}$ for $2 \mathrm{hrs} 30 \mathrm{~min}$. SDS-PAGE (12\%) was performed in reducing condition. Lane 1: fibrinogen; lanes 2-10: fibrinogen incubated with $25.0 \mathrm{ng}, 50.0 \mathrm{ng}, 0.25 \mu \mathrm{g}, 0.5 \mu \mathrm{g}, 2.0 \mu \mathrm{g}, 4.0 \mu \mathrm{g}, 5.0 \mu \mathrm{g}, 10.0$ $\mu \mathrm{g}$ and $15.0 \mu \mathrm{g}$ of MzNL, respectively. MzNL, M. zapota natant latex; SDS-PAGE, sodium dodecyl sulfate-polyacrylamide gel electrophoresis.

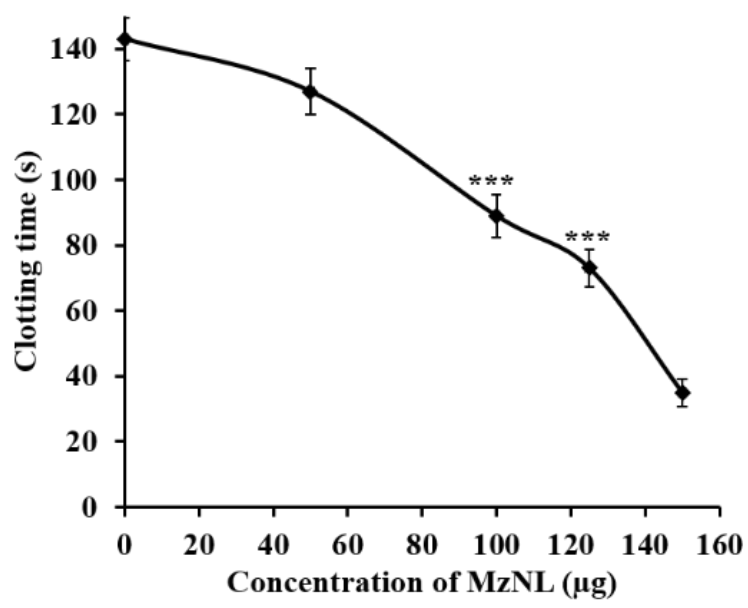

Fig. 7. Recalcification time. Different concentration of MzNL (50$150 \mu \mathrm{g} / 20 \mu \mathrm{l})$ was incubated with citrated goat plasma $(100 \mu \mathrm{l})$ for 5 min. After incubation $25 \mathrm{mM} \mathrm{CaCl}_{2}(100 \mu \mathrm{l})$ was pipette and clotting time was recorded. Values are presented as mean \pm standard error of the mean $(n=3)$. Statistically significant results are indicated by asterisks, ${ }^{* * *}-p<0.001$. MzNL, $M$. zapota natant latex.
Plant latexes have been using in folklore medicine to treat bleeding from fresh cuts, skin diseases and wound healing (5). The observed procoagulant nature of plant latex supports the scientific reason behind folklore usage of plant latexes in first line of defence against bleeding from wounds. MzNL showed collagenase activity by cleaving collagen type I and IV at the concentrations 8 and $25 \mu \mathrm{g} / 20 \mu \mathrm{l}$ respectively (Fig. 8). Collagenases have a significant role in wound care $(30,31)$. For instance, bacterial collagenases are used to treat scar tissue and to enhance the wound healing process (32). Hence, collagenolytic property of MzNL might also have role in wound healing along with hemostatic property. MzNL has not shown any hemolytic activity after treatment with RBC, indicating its nontoxic property.

\section{Conclusion}

MzNL has potent proteolytic activity associated with fibrinogenolytic activity and exhibit pro-coagulant property. Purification and characterization of the ac-
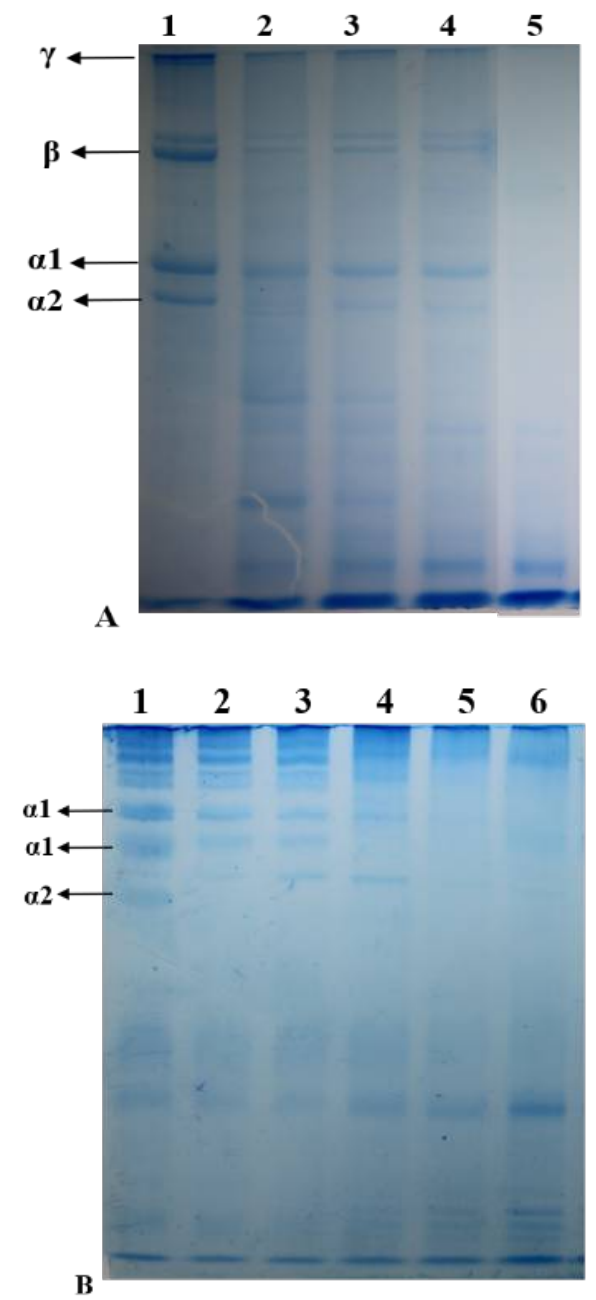

Fig. 8. Collagenolytic activity Different concentration of MzNL was treated with Type I $(10 \mu \mathrm{g})$ and IV $(25 \mu \mathrm{g})$ collagen at $37{ }^{\circ} \mathrm{C}$ for 2 hrs $30 \mathrm{~min}$. SDS-PAGE (7\%) was performed under reducing condition. A. Lane 1: $10 \mu \mathrm{g}$ collagen I; lanes 2-5: $10 \mu \mathrm{g}$ collagen I treated with 2, 4, 6 and $8 \mu \mathrm{g} / 20 \mu \mathrm{l}$ of MzNL, respectively. B. Lane 1: $25 \mu$ g collagen IV; lanes 2-6: $25 \mu$ g collagen IV treated with 2.0, 5.0, 15.0, 20.0 and $25.0 \mu \mathrm{g} / 20 \mu \mathrm{l}$ of MzNL, respectively. MzNL, $M$. zapota natant latex; SDS-PAGE, sodium dodecyl sulfate-polyacrylamide gel electrophoresis. 
tive molecule(s) will be of great interest to decipher the pathway of blood coagulation by MzNL.

\section{Authors' contributions}

CGK \& SN found the concept, involved in the experimental design, statistical analysis and data acquisition. CGK, VG, CKS, SB and HR involved in literature search, sample collection, experimental studies, manuscript preparation and review. All authors read and approved the final manuscript.

\section{Conflict of interests}

The authors declare that they have no competing interests

\section{Ethical issues}

The experiments involving animal blood (goat) were conducted in accordance with the Institutional Animal Ethical Committee, Sree Siddaganga College of Pharmacy, Tumkur with the sanctioned ethical approval number SSCPT/IAEC.clear/152A/2016-17.

\section{References}

1. Periayah MH, Halim AS, Saad AZM. Mechanism action of platelets and crucial blood coagulation pathways in hemostasis. Int J Hematol Oncol Stem Cell Res. 2017;11(4):319-27.

2. Costa JO, Fonseca KC, Garrote-Filho MS, Cunha CC, Freitas MV, Silva H.S, et al. Structural and functional comparison of proteolytic enzymes from plant latex and snake venoms. Biochimie. 2010;92:1760-65. https://doi.org/10.1016/ j.biochi.2010.09.002

3. Gubbiveeranna V, Kusuma CG, Bhavana S, Sumachirayu CK, Ravikumar H, Nagaraju S. Potent procoagulant and platelet aggregation inducing serine protease from Tridax procum bens extract. Pharmacogn Res. 2019;1:363-70. https://doi.org/ 10.4103/pr.pr_4_19

4. Raju EV, Divakar G. An overview on microbial fibrinolytic proteases. Int J Pharm Sci Res. 2013;5:643-56. https://doi.org/ 10.13040/IJPSR.0975-8232

5. Uday P, Achar RR, Poojitha BR, Rinimol VR, Bindu J, Nafeesa $\mathrm{Z}$, et al. Laticiferous plant proteases in wound care. Int J Pharm Pharm Sci. 2015;7:44-49.

6. Venkatesha SH, Rajaiah R, Vishwanayh BS. Hemostatic interference of plant latex proteases. SM J Clin Pathol. 2016;1:1002.

7. Shivaprasad HV, Riyaz M, Venkatesh KR, Dharmappa KK, Tarannum S, Siddesha JM, et al. Cysteine proteases from the Asclepiadaceae plants' latex exhibited thrombin and plasmin like activities. J Thromb Thrombolysis. 2009;28:304-08. https://doi.org/10.1007/s11239-008-0290-2

8. Bashir S. Pharmacological importance of Manilkara zapota and its bioactive constituents. Latinoam Caribe Plant Med Aromat. 2019;18:347-58. https://doi.org/10.35588/ blacpma.19.18.4.22

9. Bano M, Ahmed B. Manilkara zapota (L.) P. Royen (Sapodilla): A review. Int J Adv Res Ideas Innov Technol. 2017;3:1364-71.

10. Shafii ZA, Basri M, Malek EA, Ismail M. Phytochemical and antioxidant properties of Manilkara zapota (L.) P. Royen fruit extracts and its formulation for cosmeceutical application. Asian J Plant Sci Res. 2017;7:29-41. https://doi.org/10.5685/ plmorphol.29.41
11. Kwan. The plant observatory. Online; 2008 January 26 [cited 2020 Jun 7]. Available from: www.natureloveyou.sg

12. Reyes-Gomez S, Montiel R, Tlenkopatchev MA. Chicle gum from Sapodilla (Manilkara zapota) as a renewable resource for metathesis transformations. J Mex Chem Soc. 2018;61(1) https://doi.org/10.29356/jmcs.v62i1.581

13. Ma J, Luo XD, Protiva P, Yang $\mathrm{H}$, Ma C, Basile MJ, et al. Bioactive novel polyphenols from the fruit of Manilkara zapota (Sapodilla). J Nat Prod. 2003;66:983-86. https://doi.org/ 10.1021/np020576x

14. Jadhav SS. Sapota a wonderful fruit from nature: A review. Int J Food Sci Nutr. 2018;3:1-4.

15. Swarnakumari S, Periyanayagam K, Ida-christi VE, Mohan S Phytochemical screening and in-vitro corneal wound healing activity of the leaves of Manilkara zapota (L.) P. Royen var. Pkm1 in newer herbal drug development. World J Pharm Res. 2017;6:639-47. https://doi.org/10.20959/wjpr20179-9224

16. Satake K, Okuyama T, Ohashi M, Shinoda T. The spectrophotometric determination of amine, amino acid and peptide with 2,4,6-trinitrobenzene1-sulfonic acid. J Biochem. 1960;47:654-60. https://doi.org/10.1111/j.19498594.1960.tb08465.x

17. Laemmli UK. Cleavage of structural proteins during the as sembly of the head of bacteriophage T4. Nature. 1970;227:680-85. https://doi.org/10.1038/228549a0

18. Leach BS, Collawn JF, Fish WW. Behavior of glycopolypeptides with empirical molecular weight estimation methods. 2. In random coil producing solvents. Biochemistry. 1980;19:5741-47. https://doi.org/10.1021/bi00566a012

19. Condrea E, Yang CC, Rosenberg P. Anti-coagulant activity and plasma phosphatidylserine hydrolysis by snake venom phospholipases A2. Thromb Haemost. 1983;49(2):151. htttps://doi.org/10.1055/s-0038-1657347

20. Kim M, Hamilton S, Guddat L, Overall CM. Plant collagenase: Unique collagenolytic activity of cysteine proteases from ginger. Biochim Biophys Acta. 2008;1770:1627-35. https:// doi.org/10.1016/j.bbagen.2007.08.003

21. Shin SY, Lee MK, Kim KL, Hahm KS. Structure-antitumor and hemolytic activity relationships of synthetic peptides derived from cecropin A-magainin2 and cecropin A-melittin hybrid peptides. J Peptidr Rrs. 1997;50:279-85. https://doi.org/ 10.1111/j.1399-3011.1997.tb01469.x

22. Lowry OH, Rosebrough NJ, Farr AL, Randall RJ. Protein measurement with the folin phenol reagent. J Biol Chem. 1951;193:265-75. https://doi.org/10.1016/0304-3894(92)87011

23. Raskovic BG, Polovic ND. Collegenase activity in fig latex could contribute to its efficacy in ethnomedicinal preparations. J Herb Med. 2016;6:73-78. http://dx.doi.org/doi:10.1016 j.hermed.2016.03.002

24. Rajesh R, Shivaprasad HV, Raghavendra GCD, Nataraju A, Dhananjaya BL, Vishwanath BS. Comparative study on plant latex proteases and their involvement in hemostasis: A special emphasis on clot inducing and dissolving properties. Planta Med. 2007;73:1061-67. https://doi.org/10.1055/s-2007981575

25. Viana CA, Oliveira JS, Freitas CDT, Alencar NMN, Carvalho CPS, Nishi BC, et al. Thrombin and plasmin- like activities in the latices of Cryptostegia grandiflora and Plumeria rubra. Blood Coagul Fibrinolysis. 2013;24:386-92. https://doi.org/ 10.1097/MBC.0b013e32835d540b

26. Badgujar SB. Evaluation of hemostatic activity of latex from three Euphorbiaceae species. J Ethnopharmacol 2014;151:733-39. http://dx.doi.org/10.1016/j.jep.2013.11.044

27. Shivaprasad HV, Rajaiah R, Frey BM. Frey FJ, Vishwanath BS. 'Pergularain e I'- a plant cysteine protease with thrombin-like activity from Pergularia extensa latex. Thromb Res. 2010;125:100-05. j.thromres.2009.10.002

28. Patel GK, Kawale AA, Sharma AK. Purification and physicochemical characterization of a serine protease with fibrinolytic activity from latex of a medicinal herb Euphorbia 
hirta. Plant Physiol Biochem. 2012;52:104-11. https://doi.org/ 10.1016/j.plaphy.2011.12.004

29. Uday P, Maheshwari M, Sharanappa P, Nafeesa Z, Kameshwar VH, Priya BS, et al. Exploring hemostatic and thrombolytic potential of heynein - A cysteine protease from Ervatamia heyneana latex. J Ethnopharmacol. 2017;199:316-22. https://doi.org/10.1016/j.jep.2016.12.047

30. Frye KE, Luterman A. Decreased incidence of hypertrophic burn scar formation with the use of collagenase, an enzymatic debriding agent. Wounds. 2005;17:332-36.
31. Hurst LC, Badalamente MA, Hentz VR, Hotchkiss RN, Kaplan FT, Meals RA, et al Injectable collagenase Clostridium histolyticum for dupuytren's contracture. $N$ Engl J Med. 2009;361:968-79. https://doi.org/10.1056/NEJMoa0810866

32. Onesti MG, Fioramonti P, Carella S, Fino P, Sorvillo V, Scuderi N. A new association between hyaluronic acid and collagenase in wound repair: an open study. Eur Rev Med Pharmacol Sci. 2013;17:210-16. 